Prepared in cooperation with U.S. Department of Agriculture Forest Service, Lincoln National Forest

\title{
Postwildfire Debris-Flow Hazard Assessment of the Area Burned by the 2012 Little Bear Fire, South-Central New Mexico
}
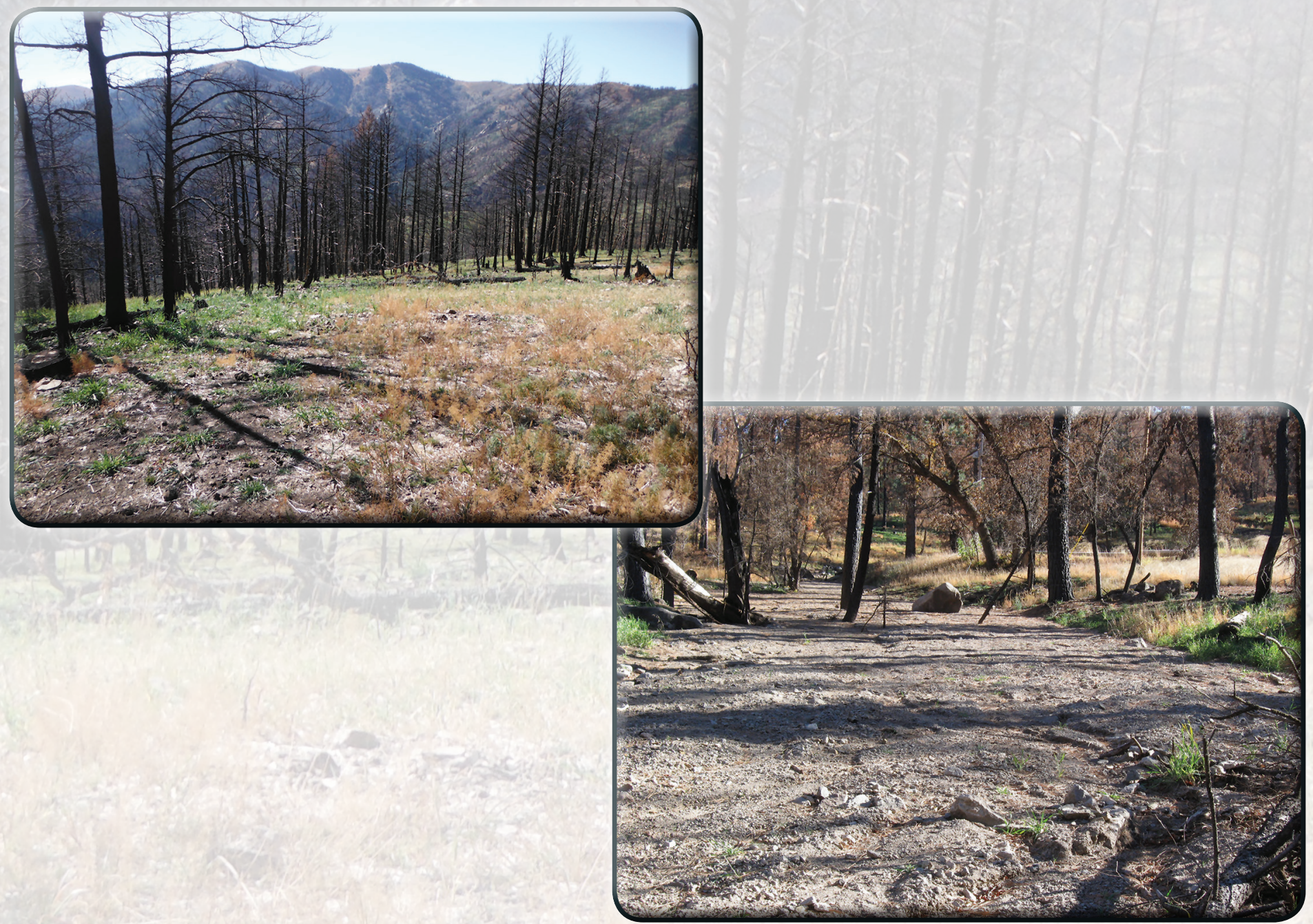

Open-File Report 2013-1108 


\section{Front cover:}

Top, Severely burned hillslope, Little Bear Fire, 2012, south-central New Mexico.

Bottom, Sediment deposition at the mouth of Spring Canyon following the Little Bear Fire, 2012, southcentral New Mexico.

\section{Back cover:}

Top, Example of steep terrain in the area burned by the Little Bear Fire, 2012, south-central New Mexico.

Middle and bottom, Severely burned hillslope with fall vegetation regrowth, near Monjeau Peak, following the Little Bear Fire, 2012, south-central New Mexico. 


\section{Postwildfire Debris-Flow Hazard Assessment of the Area Burned by the 2012 Little Bear Fire, South-Central New Mexico}

By Anne C. Tillery and Anne Marie Matherne

Prepared in cooperation with U.S. Department of Agriculture Forest Service, Lincoln National Forest

Open-File Report 2013-1108 


\title{
U.S. Department of the Interior \\ SALLY JEWELL, Secretary
}

\author{
U.S. Geological Survey \\ Suzette M. Kimball, Acting Director
}

U.S. Geological Survey, Reston, Virginia: 2013

For more information on the USGS - the Federal source for science about the Earth, its natural and living resources, natural hazards, and the environment, visit http://www.usgs.gov or call 1-888-ASK-USGS.

For an overview of USGS information products, including maps, imagery, and publications, visit http://www.usgs.gov/pubprod

To order this and other USGS information products, visit http://store.usgs.gov

Any use of trade, firm, or product names is for descriptive purposes only and does not imply endorsement by the U.S. Government.

Although this information product, for the most part, is in the public domain, it also may contain copyrighted materials as noted in the text. Permission to reproduce copyrighted items must be secured from the copyright owner.

Suggested citation:

Tillery, A.C., and Matherne, A.M., 2013, Postwildfire debris-flow hazard assessment of the area burned by the 2012 Little Bear Fire, south-central New Mexico: U.S. Geological Survey Open-File Report 2013-1108, 15 p., 3 pls., http://pubs.usgs.gov/of/2013/1108/. 


\section{Acknowledgments}

Barbara Ruddy and Dennis Staley of the U.S. Geological Survey performed technical reviews of the report. 



\section{Contents}

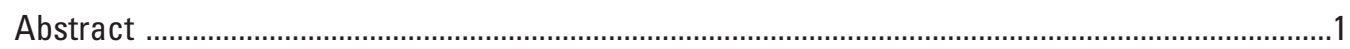

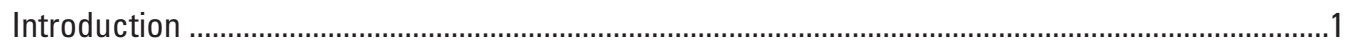

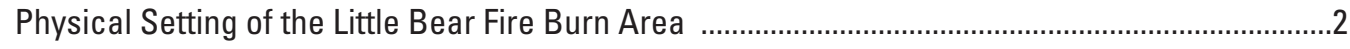

Methods Used To Estimate Debris-Flow Hazards ........................................................................

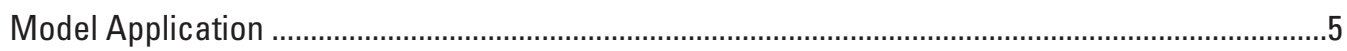

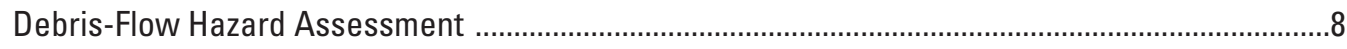

Debris-Flow Probability Estimates .....................................................................................

Debris-Flow Volume Estimates ..........................................................................................

Combined Relative Debris-Flow Hazard Rankings .................................................................11

Limitations of Hazard Assessments ......................................................................................11

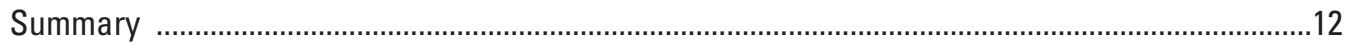

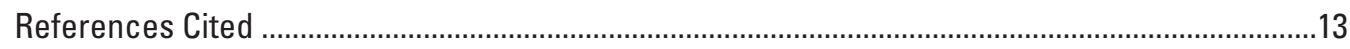

\section{Plates}

(Available online at http://pubs.usgs.gov/of/2013/1108/.)

1. Estimated probability of postwildfire debris flows in the area burned by the 2012 Little Bear Fire, south-central New Mexico

2. Estimated volume of postwildfire debris flows in the area burned by the 2012 Little Bear Fire, south-central New Mexico

3. Combined probability and volume relative hazard ranking of postwildfire debris flows in the area burned by the 2012 Little Bear Fire, south-central New Mexico

\section{Figures}

1. Map showing Little Bear Fire burn severity, as established by the Burned Area Emergency Response (BAER) Team, June 28, 2012. Modified from data supplied by the U.S. Department of Agriculture Forest Service, Little Bear Fire BAER Team ........3

2. Photograph showing sediment deposition at the mouth of Spring Canyon following the Little Bear Fire, south-central New Mexico, summer 2012. Rio Bonito is in the foreground

3. Photograph showing North Fork Eagle Creek near Alto, New Mexico (08387550), streamgage before and after the Little Bear Fire in 2012. $A$, View from below weir, 2007 (photograph by Patrick Swift). B, View from above weir, 2013

\section{Table}

1. Estimated debris-flow probabilities and volumes for the 2012 Little Bear Fire, southcentral New Mexico 


\section{Conversion Factors}

\begin{tabular}{lcl}
\hline \multicolumn{1}{c}{ Multiply } & By & \multicolumn{1}{c}{ To obtain } \\
\hline millimeter $(\mathrm{mm})$ & Length & inch (in.) \\
meter $(\mathrm{m})$ & 0.03937 & foot (ft) \\
kilometer $(\mathrm{km})$ & 3.281 & mile (mi) \\
\hline & 0.6214 & acre \\
\hline hectare $(\mathrm{ha})$ & Area & acre \\
square kilometer $\left(\mathrm{km}^{2}\right)$ & 2.471 & square mile $\left(\mathrm{mi}^{2}\right)$ \\
square kilometer $\left(\mathrm{km}^{2}\right)$ & 247.1 & square foot $\left(\mathrm{ft}^{2}\right)$ \\
square meter $\left(\mathrm{m}^{2}\right)$ & 0.3861 & \\
\hline & 10.76 & cubic foot $\left(\mathrm{ft}^{3}\right)$ \\
\hline cubic meter $\left(\mathrm{m}^{3}\right)$ & Volume & inch per hour $(\mathrm{in} / \mathrm{h})$ \\
\hline
\end{tabular}

Vertical coordinate information is referenced to the North American Vertical Datum of 1988 (NAVD 88).

Horizontal coordinate information is referenced to the North American Datum of 1983 (NAD 83). 


\title{
Postwildfire Debris-Flow Hazard Assessment of the Area Burned by the 2012 Little Bear Fire, South-Central New Mexico
}

\author{
By Anne C. Tillery and Anne Marie Matherne
}

\section{Abstract}

A preliminary hazard assessment was developed of the debris-flow potential from 56 drainage basins burned by the Little Bear Fire in south-central New Mexico in June 2012. The Little Bear Fire burned approximately 179 square kilometers $\left(\mathrm{km}^{2}\right)\left(44,330\right.$ acres), including about $143 \mathrm{~km}^{2}$ (35,300 acres) of National Forest System lands of the Lincoln National Forest. Within the Lincoln National Forest, about $72 \mathrm{~km}^{2}$ (17,664 acres) of the White Mountain Wilderness were burned. The burn area also included about $34 \mathrm{~km}^{2}$ ( 8,500 acres) of private lands. Burn severity was high or moderate on 53 percent of the burn area. The area burned is at risk of substantial postwildfire erosion, such as that caused by debris flows and flash floods.

A postwildfire debris-flow hazard assessment of the area burned by the Little Bear Fire was performed by the U.S. Geological Survey in cooperation with the U.S. Department of Agriculture Forest Service, Lincoln National Forest. A set of two empirical hazard-assessment models developed by using data from recently burned drainage basins throughout the intermountain Western United States was used to estimate the probability of debris-flow occurrence and volume of debris flows along the burn area drainage network and for selected drainage basins within the burn area. The models incorporate measures of areal burn extent and severity, topography, soils, and storm rainfall intensity to estimate the probability and volume of debris flows following the fire. Relative hazard rankings of postwildfire debris flows were produced by summing the estimated probability and volume ranking to illustrate those areas with the highest potential occurrence of debris flows with the largest volumes.

The probability that a drainage basin could produce debris flows and the volume of a possible debris flow at the basin outlet were estimated for three design storms: (1) a 2-year-recurrence, 30-minute-duration rainfall of 27 millimeters ( $\mathrm{mm}$ ) (a 50 percent chance of occurrence in any given year); (2) a 10-year-recurrence, 30-minute-duration rainfall of $42 \mathrm{~mm}$ (a 10 percent chance of occurrence in any given year); and (3) a 25-year-recurrence, 30-minute-duration rainfall of $51 \mathrm{~mm}$ (a 4 percent chance of occurrence in any given year). Thirty-nine percent of the 56 drainage basins modeled have a high (greater than 80 percent) probability of debris flows in response to the 2-year design storm; 80 percent of the modeled drainage basins have a high probability of debris flows in response to the 25 -year design storm. For debris-flow volume, 7 percent of the modeled drainage basins have an estimated debris-flow volume greater than 100,000 cubic meters $\left(\mathrm{m}^{3}\right)$ in response to the 2-year design storm; 9 percent of the drainage basins are included in the greater than $100,000 \mathrm{~m}^{3}$ category for both the 10 -year and the 25 -year design storms. Drainage basins in the greater than $100,000 \mathrm{~m}^{3}$ volume category also received the highest combined hazard ranking.

The maps presented herein may be used to prioritize areas where emergency erosion mitigation or other protective measures may be needed prior to rainstorms within these drainage basins, their outlets, or areas downstream from these drainage basins within the 2- to 3-year period of vulnerability. This work is preliminary and is subject to revision. The assessment herein is provided on the condition that neither the U.S. Geological Survey nor the U.S. Government may be held liable for any damages resulting from the authorized or unauthorized use of the assessment.

\section{Introduction}

In June 2012, the Little Bear Fire burned approximately 179 square kilometers $\left(\mathrm{km}^{2}\right)(44,330$ acres $)$ in south-central New Mexico, including about $143 \mathrm{~km}^{2}(35,300$ acres) of National Forest System lands of the Lincoln National Forest (pl. 1). Within the Lincoln National Forest, about $72 \mathrm{~km}^{2}$ (17,664 acres) of the White Mountain Wilderness were burned, including 22.7 kilometers (14.1 miles) of Outstanding National Resource Waters within the upper and middle Rio Bonito drainage basin (Snyder and others, 2012). Outstanding National Resource Waters have been designated by the New Mexico Water Quality Control Commission to receive special protection against degradation under New Mexico water quality standards and the Federal Clean Water Act (New Mexico Environment Department, 2013). Affected waters with the Outstanding National Resource Waters designation included parts of Bonito Creek, Argentina Creek, Little Bonito 
Postwildfire Debris-Flow Hazard Assessment of the Area Burned by the 2012 Little Bear Fire, South-Central New Mexico

Creek, Aspen Creek, Turkey Creek, Roadmaker Creek, and Mills Creek (pl. 1). The burn area also included about $34 \mathrm{~km}^{2}$ (8,500 acres) of private lands. A total of 254 structures were destroyed, of which 242 were residences (Payne and Beach, 2012; Snyder and others, 2012).

Debris flows have been documented after many fires in the Western United States (Cannon and others, 2007, 2010; DeGraff and others, 2011). Rainfall on burn areas can result in transport and deposition of large volumes of sediment, both within and downchannel from burn areas. The rapid transport of large amounts of material makes debris flows particularly dangerous. In addition, debris flows following a wildfire can occur in places where flooding or sedimentation has not been observed in the past and can be generated in response to shortduration and low-recurrence-interval rainfall (Cannon and others, 2007, 2010; DeGraff and others, 2011).

The hydrologic response of drainage basins intensifies under postwildfire conditions of decreased vegetation cover and altered soil properties. Wildfires can consume rainfallintercepting canopy, litter, and duff (Moody and Martin, 2001a, 2001b; Cannon and Gartner, 2005). Water-repellent qualities in some soils can be increased or induced by the intense heat of a wildfire (DeBano, 1981; Doerr and others, 2000; Letey, 2001; Woods and others, 2006), and increased overland flow and erosion can occur as a result (Wells, 1987; Moody and Martin, 2001a, 2001b). Fine ash, which may expand when wetted, can block soil pore spaces and further reduce infiltration of water (Romkens and others, 1990; Woods and others, 2006). After a wildfire, the drainage basin response to rainfall events shifts, in general terms, from infiltration dominated to runoff dominated (Cannon and others, 2010). Because of reduced soil infiltration, rainfall on wildfire burn scars can run off almost immediately as overland flow. This runoff in low-order channels can erode surficial materials, producing a flow that is rich in ash, soil, boulders, and dislodged vegetation. As additional sediment is entrained, sediment-laden flow in channels can transition into debris flows that can affect lives, property, infrastructure, aquatic habitats, and water supplies (Cannon and Gartner, 2005). Debris flows are most frequent within 2-3 years after wildfires, when vegetative cover is absent or reduced and abundant materials are available for erosion and transport (Cannon and Gartner, 2005; Cannon and others, 2010). Variability in climatic conditions following a wildfire, such as an extended period that is wetter or dryer than normal, could result in variability in this period of vulnerability.

The area burned by the Little Bear Fire is at risk of substantial postwildfire erosion, such as that caused by debris flows and flash floods. A postwildfire debris-flow hazard assessment of the area burned by the Little Bear Fire was performed by the U.S. Geological Survey (USGS) in cooperation with the U.S. Department of Agriculture (USDA) Forest Service, Lincoln National Forest. The purpose of this report is to present a preliminary hazard assessment of the debris-flow potential for drainage basins burned by the 2012 Little Bear Fire. Similar assessments of postwildfire debris-flow potential have been developed for earlier largescale New Mexico wildfires, including the Track (Tillery and others, 2011a), Las Conchas (Tillery and others, 2011b), and Whitewater-Baldy Complex Fires (Tillery and others, 2012).

\section{Physical Setting of the Little Bear Fire Burn Area}

The Little Bear Fire started on the northeast flank of Sierra Blanca Peak and burned northeast across the Rio Bonito drainage basin and other drainage basins in the mountains adjacent to Alto, Villa Madonna, Angus, and several other small communities (pl. 1). Burn severity was high or moderate on 53 percent of the burn area (fig. 1). The terrain within the burn area is composed of very steep and rugged mountains and interspersed valleys with vegetation ranging from pinyonjuniper (Pinus and Juniperus spp.) scrub at an elevation of about 2,000 meters $(\mathrm{m})(6,500 \mathrm{feet}[\mathrm{ft}])$ to mixed conifer and alpine grasslands at an elevation higher than $3,600 \mathrm{~m}$ $(11,900 \mathrm{ft})$. Numerous steep and short drainages converge into larger streams with the potential to transport substantial water and debris during postfire rain events (Snyder and others, 2012). High-severity burn areas in the White Mountain Wilderness were identified in the headwaters of Big Bear Canyon, Dark Betsy Canyon, and South Fork Rio Bonito, among others (fig. 1). These drainage basins drain into the Rio Bonito, which drains into Bonito Lake. Bonito Lake provides 60 percent of the municipal water for the City of Alamogordo and Holloman Air Force Base, about $64 \mathrm{~km}$ (40 mi) southwest of Sierra Blanca Peak (Snyder and others, 2012). High- to moderate-severity burn conditions also occurred in parts of Little Creek drainage basin, in the vicinity of the community of Villa Madonna, and in parts of North Fork Eagle Creek drainage basin, which includes the Village of Ruidoso municipal wells and a group of historic USDA Forest Service cabins (Matherne and others, 2010; Snyder and others, 2012). Alto Reservoir, located on Eagle Creek downstream from the burn area, provides a portion of the Village of Ruidoso municipal water supply. The Village of Ruidoso lies about $10 \mathrm{~km}(6 \mathrm{mi})$ south of Alto Reservoir. Drainage basins along Highway 532 above Alto Reservoir and parts of Magado Creek drainage basin in the northeastern part of the burn area were also affected (Snyder and others, 2012).

Geologically, the area is composed primarily of igneous intrusive and volcanic rocks of Tertiary age (Thompson, 1972), including tuff deposits, and volcaniclastic sedimentary and lahar deposits (Rawling, 2011). More recent sedimentary and secondary tuff deposits are found in the eastern part of the burn area (Green and Jones, 1997; Weldon, 2012). Soils within the burn area are composed primarily of residuum derived from the underlying volcanic or sedimentary sources, colluvium, and alluvium. Soils within the burn area are highly variable, ranging from shallow to deep, fine to loamy, and skeletal to nonskeletal in nature and occur on slopes ranging from 0 to 80 percent (Hill and others, 2012). 


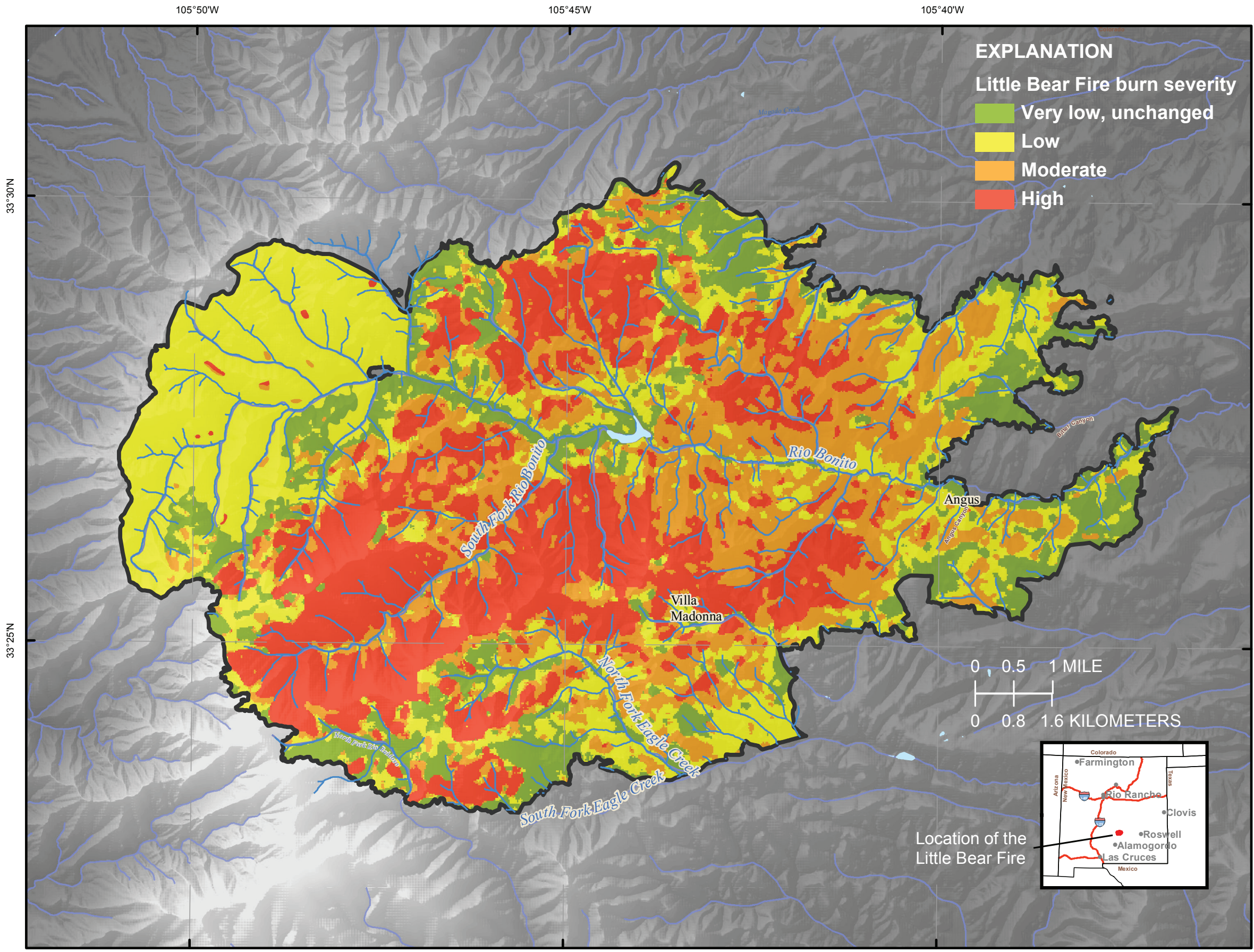

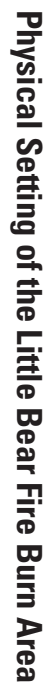

Figure 1. Little Bear Fire burn severity, as established by the Burned Area Emergency Response (BAER) Team, June 28, 2012. Modified from data supplied by the U.S. Department of Agriculture Forest Service, Little Bear Fire BAER Team. 


\section{Methods Used To Estimate Debris-Flow Hazards}

For this preliminary hazard assessment, a set of two empirical hazard-assessment models was used to estimate the probability of debris flow and to estimate debris-flow volume. The model outputs were combined to produce a relative ranking of debris-flow hazard along drainage networks and for selected drainage basins in response to three design storms in the Little Bear Fire burn area. The model for predicting debrisflow probability was developed by Cannon and others (2010) by using logistic multiple-regression analyses of data from 388 drainage basins in 15 burn areas in the intermountain Western United States. Conditions in each basin were quantified by using readily obtained measures of burn extent and severity, hillslope gradient, soil properties, and storm rainfall. Statistical analyses were used to identify the variables that most strongly influenced debris-flow occurrence and to build the predictive model. Equation 1 is used to calculate debris-flow probability (Cannon and others, 2010):

$$
P=e^{x} /\left(1+e^{x}\right),
$$

where

$$
\begin{gathered}
P \quad \text { is the probability of debris-flow occurrence in } \\
\text { fractional form, and } \\
e^{x} \quad \text { is the exponential function where } e \text { represents } \\
\text { the mathematical constant } 2.718 .
\end{gathered}
$$

Equation 2 is used to calculate $x$ :

$$
\begin{gathered}
x=-0.7+0.03(\% S G 30)-1.6(R)+0.06(\% A B) \\
+0.07(I)+0.2(\% C)-0.4(L L),
\end{gathered}
$$

where

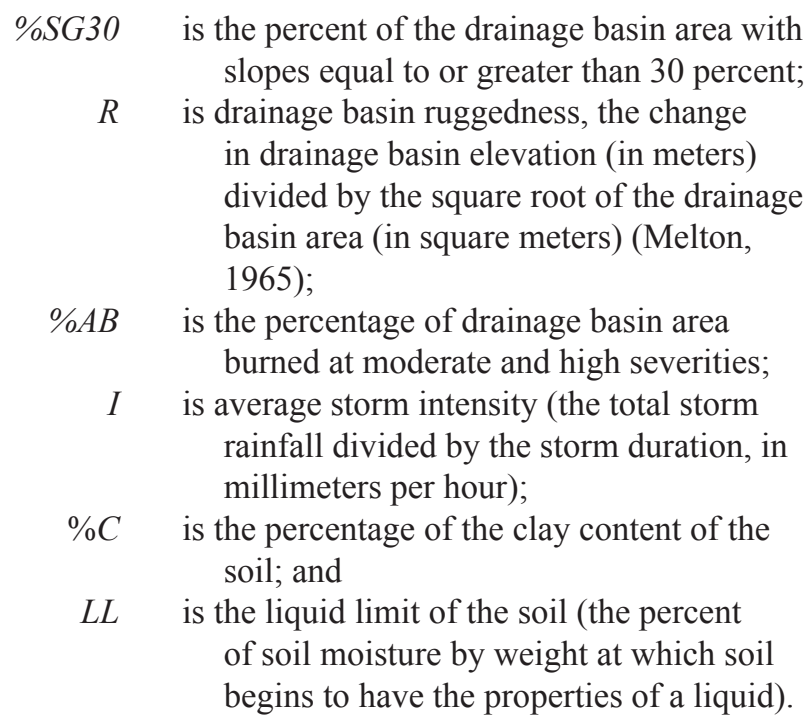

A second statistical model was used to estimate the volume of material that could issue from the basin outlet of a recently burned drainage basin in response to a given magnitude storm. This model was developed by using multiple linear-regression analyses of data compiled from 56 debrisflow-producing drainage basins burned by eight fires (Cannon and others, 2010). Debris-flow volume measurements were derived from records of the amount of material removed from sediment-retention basins and from field measurements of the amount of material eroded from the main channels within a burned drainage basin. Statistical analyses were used to identify the variables that most strongly influenced debrisflow volume. The model provides estimates of the volume of material that may pass through a drainage-basin outlet in response to a single rain event. The model has the following form:

$$
\begin{aligned}
& \operatorname{Ln}(V)=7.2+0.6(\operatorname{Ln}(S G 30)) \\
& +0.7(A B)^{0.5}+0.2(T)^{0.5}+0.3
\end{aligned}
$$

where

$$
\begin{aligned}
& \text { Ln is the natural log function; } \\
& V \quad \text { is the debris-flow volume (in cubic meters); } \\
& S G 30 \text { is the drainage basin area with slopes equal } \\
& \text { to or greater than } 30 \text { percent (in square } \\
& \text { kilometers); } \\
& A B \quad \text { is the drainage basin area burned at moderate } \\
& \text { and high severities (in square kilometers); } \\
& T \text { is the total storm rainfall (in millimeters); and } \\
& 0.3 \text { is a bias-correction factor that changes the } \\
& \text { predicted estimate from a median to a } \\
& \text { mean value (Helsel and Hirsch, 2002; } \\
& \text { Cannon and others, 2010). }
\end{aligned}
$$

Values for both probability and volume were obtained along drainage networks by using the continuous parameterization technique (Verdin and Greenlee, 2003; Verdin and Worstell, 2008). With this technique, estimates of debris-flow probability and volume (Cannon and others, 2010) were obtained for every $10-\mathrm{m}$ pixel along the drainage network (pls. 1 and 2) as a function of conditions in the drainage basin upstream from each pixel. This technique was developed as an alternative to basin-characterization approaches used in the past (for example, Cannon and others, 2010), which require definition of outlets and their corresponding drainage basins at the beginning of the analysis. The technique used here allows for a synoptic view of conditions throughout the study area, which can be used to identify specific $10-\mathrm{m}$ pixels or stream reaches within a basin that might pose a higher risk of debris flows; the technique also aids in sampling design and monitoring-site selection.

The base layer upon which the continuousparameterization layers were built is the $1 / 3$-arc-second National Elevation Dataset (Gesch and others, 2002). This digital elevation model (DEM) was transformed into a projection system appropriate to the study area (Universal Transverse Mercator, Zone 13) and processed by using standard DEM-conditioning tools in ArcGIS (Environmental Systems Research Institute, Inc., 2009) and RiverTools (Rivix, LLC, 2012). The DEM was used to derive the overland 
flow structure in the form of a flow-direction matrix in eight directions. The flow-direction matrix and a weighted flow accumulation algorithm were then used to derive values of the independent spatial variables driving the probability and volume equations for every grid cell within the extent of the DEM.

Because of orographic effects of the mountainous terrain and the size of the burn area, actual storm rainfall totals and intensities will vary in both space and time. For this study, however, the maximum rainfall of the design storm was assumed to be uniform over the entire burn area, providing the most conservative estimate of the probability and volumes of potential debris flows. Values for all of the other independent variables driving the debris-flow probability and volume equations were obtained by using the continuousparameterization approach. The independent-variable values can be represented as forming continuous surfaces over the burn area. Once the surfaces of the independent variables were developed, the probability and volume equations were solved by using map algebra for each grid cell along the drainage network, thus deriving the probability and volume surfaces. Along the drainage network, drainage basins were delineated so that the area of the basin at the farthest downstream pixel modeled was within the size range for which the models were developed, $0.01-103 \mathrm{~km}^{2}$ for the probability model and $0.01-$ $27.9 \mathrm{~km}^{2}$ for the volume model (Cannon and others, 2010). Identification of the probability or volume of a debris flow at locations within the study area can be obtained by querying the derived surfaces.

Debris-flow hazards from a given basin can also be represented by a combined relative debris-flow hazard ranking that is based on a combination of both probability of occurrence and volume (Cannon and others, 2010). For this assessment, the estimated values of debris-flow probability and volume were categorized into relatively ranked classes, and these classes were added together to calculate the combined probability and volume relative hazard ranking (pl. 3). This combined ranking identifies a possible range of responses from drainage basins with the highest probabilities of producing debris flows with the largest volumes to drainage basins with the lowest probabilities of producing debris flows with the smallest volumes (Cannon and others, 2010). For example, the most hazardous drainage basins will have both the highest probabilities of occurrence and the largest estimated volumes of material. Slightly less hazardous would be drainage basins modeled with a combination of either low probabilities and larger volume estimates or high probabilities and smaller volume estimates.

\section{Model Application}

Debris-flow probabilities and volumes were calculated along the drainage networks for the Little Bear Fire burn area by using the two empirical models. Within the area analyzed, 56 drainage basins were delineated and numbered to aid in discussion of model results (pl. 1 and table 1). Smaller side drainage basins were not delineated and numbered, but these drainage basins were included in the stream segment analysis. Probability, volume, or hazard ranking for the numbered drainage basins represents the value at the basin outlet. Probability or hazard rankings may be higher or lower and volume rankings may be smaller for subbasins or points within the delineated drainage basins, as indicated by the stream segment analysis within the drainage basins. The drainage basins were delineated by analyzing elevation data derived from 10-m DEMs (U.S. Geological Survey, 2011) with geographic information system (GIS) hydrological tools. Debris-flow probability and volume were estimated for every $10-\mathrm{m}$ pixel along mapped drainage networks of the burn area as a function of conditions in the modeled drainage basin above each pixel (Verdin and Greenlee, 2003; Verdin and Worstell, 2008). Drainage basins were delineated so that the area of the basin at the farthest downstream pixel modeled was within the size range for which the models were developed, $0.01-103 \mathrm{~km}^{2}$ for the probability model and $0.01-27.9 \mathrm{~km}^{2}$ for the volume model (Cannon and others, 2010). Drainage basins with a total area exceeding the range of the volume model or for which more detailed information about tributary drainage basins was desired, such as Rio Bonito and North Fork Eagle Creek, were subdivided into side tributaries. Stream reaches draining the large drainage basins are highlighted on plates 1 through 3 as "drainages within burn areas that can be affected by the combined effects of debris flows generated from side tributaries." For large drainage basins falling within the size range of the probability model but outside the size range of the volume model, probability estimates are indicated along the streamline by segment, but no basin number is assigned for the combined basin, and no relative hazard ranking is calculated. Areas for drainage basins analyzed for volume and relative hazard ranking averaged $2.7 \mathrm{~km}^{2}$ and ranged from $0.4 \mathrm{~km}^{2}$ to $15.1 \mathrm{~km}^{2}$.

Measures of the physical properties of soils within each basin were obtained from the State Soil Geographic (STATSGO) database (Schwartz and Alexander, 1995). If more than one soil unit was mapped within a given basin, a spatially weighted average of the soil variable values was calculated. The clay content and liquid limit of soils in drainage basins burned by the Little Bear Fire covered a narrow range, about $28-35$ percent for clay content and about 31-36 percent for the liquid limit.

The Burned Area Emergency Response (BAER) Image Support Team of the USGS Earth Resources Observation and Science (EROS) Center and the USDA Forest Service Remote Sensing Applications Center provided a map of Burned Area Reflectance Classification (BARC), which was used as an indicator of the distribution of burn severity within the fire perimeter (U.S. Department of Agriculture Forest Service, written commun., 2012). The BARC map for the Little Bear Fire indicates that the moderate- and high-severity burn areas totaled about $95 \mathrm{~km}^{2}$ (23,500 acres), 53 percent of the total burn area. The high-severity burn area includes South Fork 
Table 1. Estimated debris-flow probabilities and volumes for the 2012 Little Bear Fire, south-central New Mexico.

[mm, millimeters; $\mathrm{km}^{2}$, square kilometers; \%, percent; $\mathrm{m}^{3}$, cubic meters; $<$, less than; $>$, greater than]

\begin{tabular}{|c|c|c|c|c|c|c|c|c|c|c|c|c|}
\hline \multirow{3}{*}{$\begin{array}{c}\text { Selected } \\
\text { basin }\end{array}$} & \multirow{3}{*}{ Description } & \multirow{3}{*}{$\begin{array}{c}\text { Percent } \\
\text { of basin } \\
\text { with } \\
\text { slope } \\
\text { greater } \\
\text { than } 30 \%\end{array}$} & \multirow{3}{*}{$\begin{array}{l}\text { Drainage } \\
\text { area } \\
\left(\mathrm{km}^{2}\right)\end{array}$} & \multirow{2}{*}{\multicolumn{3}{|c|}{$\begin{array}{c}\begin{array}{c}\text { 2-year-recurrence, } \\
\text { 30-minute-duration rainfall }\end{array} \\
27 \mathrm{~mm}\end{array}$}} & \multirow{2}{*}{\multicolumn{3}{|c|}{$\begin{array}{c}\begin{array}{c}\text { 10-year-recurrence, } \\
\text { 30-minute-duration rainfall }\end{array} \\
42 \mathrm{~mm} \\
\end{array}$}} & \multirow{2}{*}{\multicolumn{3}{|c|}{$\begin{array}{c}\begin{array}{c}\text { 25-year-recurrence, } \\
\text { 30-minute-duration rainfall }\end{array} \\
51 \mathrm{~mm}\end{array}$}} \\
\hline & & & & & & & & & & & & \\
\hline & & & & $\begin{array}{l}\text { Prob- } \\
\text { ability } \\
(\%)\end{array}$ & $\begin{array}{c}\text { Volume } \\
\left(\mathrm{m}^{3}\right)\end{array}$ & $\begin{array}{l}\text { Combined } \\
\text { hazard } \\
\text { ranking }\end{array}$ & $\begin{array}{l}\text { Prob- } \\
\text { ability } \\
(\%)\end{array}$ & $\begin{array}{c}\text { Volume } \\
\left(\mathrm{m}^{3}\right)\end{array}$ & $\begin{array}{l}\text { Combined } \\
\text { hazard } \\
\text { ranking }\end{array}$ & $\begin{array}{l}\text { Prob- } \\
\text { ability } \\
(\%)\end{array}$ & $\begin{array}{c}\text { Volume } \\
\left(\mathrm{m}^{3}\right)\end{array}$ & $\begin{array}{l}\text { Combined } \\
\text { hazard } \\
\text { ranking }\end{array}$ \\
\hline 1 & Cherry Creek & 57.2 & 2.22 & 41 & 17,489 & 3 & 86 & 25,469 & 4 & 96 & 30,780 & 4 \\
\hline 2 & Grapevine Canyon & 66.7 & 0.53 & $<20$ & $<5,000$ & 1 & 31 & 6,511 & 2 & 61 & 7,869 & 3 \\
\hline 3 & Unnamed tributary to Magado Creek & 28.3 & 1.44 & $<20$ & 5,416 & 1 & $<20$ & 7,888 & 1 & 39 & 9,533 & 2 \\
\hline 4 & Unnamed tributary to Magado Creek & 33.1 & 2.54 & 20 & 14,373 & 2 & 68 & 20,932 & 3 & 88 & 25,297 & 4 \\
\hline 5 & Ferguson Canyon & 31.4 & 1.18 & 35 & 7,555 & 2 & 83 & 11,003 & 4 & 94 & 13,297 & 4 \\
\hline 6 & Unnamed tributary to Magado Creek & 16.5 & 1.61 & 62 & 7,814 & 3 & 93 & 11,380 & 4 & 98 & 13,753 & 4 \\
\hline 7 & Unnamed tributary to Magado Creek & 2.9 & 1.11 & 24 & $<5,000$ & 2 & 74 & $<5,000$ & 3 & 91 & $<5,000$ & 3 \\
\hline 8 & Crocket Canyon & 5.4 & 4.10 & 26 & 9,304 & 2 & 75 & 13,549 & 3 & 92 & 16,374 & 4 \\
\hline 9 & Unnamed tributary to Magado Creek & 1.7 & 2.09 & $<20$ & $<5,000$ & 1 & $<20$ & $<5,000$ & 1 & 33 & $<5,000$ & 2 \\
\hline 10 & Unnamed tributary to Bitter Canyon & 0.2 & 1.45 & $<20$ & $<5,000$ & 1 & $<20$ & $<5,000$ & 1 & 38 & $<5,000$ & 1 \\
\hline 11 & Little Bonito Creek & 58.3 & 1.88 & $<20$ & 9,671 & 1 & 43 & 14,084 & 3 & 73 & 17,020 & 3 \\
\hline 12 & Upper Bonito Creek/Aspen Canyon & 79.7 & 7.59 & $<20$ & 32,698 & 2 & 61 & 47,619 & 3 & 85 & 57,548 & 4 \\
\hline 13 & Little Bear Canyon & 90.3 & 4.18 & 33 & 31,985 & 2 & 81 & 46,580 & 4 & 94 & 56,292 & 4 \\
\hline 14 & Unnamed tributary to Bonito Creek & 85.1 & 0.59 & $<20$ & 5,757 & 1 & 60 & 8,384 & 2 & 84 & 10,132 & 4 \\
\hline 15 & Argentina Canyon & 70.2 & 4.01 & $<20$ & 16,451 & 2 & 50 & 23,958 & 3 & 78 & 28,953 & 3 \\
\hline 16 & Turkey Canyon & 82.8 & 4.76 & $<20$ & 19,793 & 2 & 60 & 28,825 & 3 & 84 & 34,836 & 4 \\
\hline 17 & Bear Creek & 86.6 & 7.92 & 86 & $>100,000$ & 5 & 98 & $>100,000$ & 5 & 99 & $>100,000$ & 5 \\
\hline 18 & Tanbark Canyon & 79.3 & 6.65 & $<20$ & 33,147 & 2 & 64 & 48,273 & 3 & 87 & 58,338 & 4 \\
\hline 19 & Unnamed tributary to Bonito Creek & 88.4 & 0.70 & 98 & 10,282 & 4 & 100 & 14,974 & 4 & 100 & 18,096 & 4 \\
\hline 20 & George Washington Canyon & 85.8 & 1.12 & 93 & 14,584 & 4 & 99 & 21,239 & 4 & 100 & 25,667 & 4 \\
\hline 21 & Dark Betsy Canyon & 86.6 & 2.77 & 98 & 41,197 & 4 & 100 & 59,997 & 4 & 100 & 72,507 & 4 \\
\hline 22 & South Fork Rio Bonito & 93.6 & 15.10 & 98 & $>100,000$ & 5 & 100 & $>100,000$ & 5 & 100 & $>100,000$ & 5 \\
\hline 23 & Bluefront Canyon & 87.5 & 2.55 & 96 & 35,523 & 4 & 100 & 51,733 & 4 & 100 & 62,519 & 4 \\
\hline 24 & Wallsmith Canyon & 87.6 & 2.22 & 98 & 32,559 & 4 & 100 & 47,416 & 4 & 100 & 57,303 & 4 \\
\hline 25 & Roadmaker Canyon & 88.5 & 2.37 & 97 & 33,847 & 4 & 100 & 49,293 & 4 & 100 & 59,571 & 4 \\
\hline 26 & Littleton Canyon & 78.0 & 3.99 & 86 & 46,859 & 4 & 98 & 68,242 & 4 & 99 & 82,471 & 4 \\
\hline 27 & Anan Canyon & 73.8 & 6.80 & 96 & $>100,000$ & 5 & 99 & $>100,000$ & 5 & 100 & $>100,000$ & 5 \\
\hline 28 & Beal Canyon & 92.8 & 1.32 & 95 & 18,580 & 4 & 99 & 27,059 & 4 & 100 & 32,701 & 4 \\
\hline 29 & Spring Canyon & 87.7 & 1.45 & 97 & 20,547 & 4 & 100 & 29,923 & 4 & 100 & 36,162 & 4 \\
\hline
\end{tabular}


Table 1. Estimated debris-flow probabilities and volumes for the 2012 Little Bear Fire, south-central New Mexico.—Continued

[mm, millimeters; $\mathrm{k}^{2}$, square kilometers; \%, percent; $\mathrm{m}^{3}$, cubic meters; <, less than; >, greater than]

\begin{tabular}{|c|c|c|c|c|c|c|c|c|c|c|c|c|}
\hline \multirow{3}{*}{$\begin{array}{l}\text { Selected } \\
\text { basin }\end{array}$} & \multirow{3}{*}{ Description } & \multirow{3}{*}{$\begin{array}{c}\text { Percent } \\
\text { of basin } \\
\text { with } \\
\text { slope } \\
\text { greater } \\
\text { than } 30 \%\end{array}$} & \multirow{3}{*}{$\begin{array}{l}\text { Drainage } \\
\text { area } \\
\left(\mathrm{km}^{2}\right)\end{array}$} & \multirow{2}{*}{\multicolumn{3}{|c|}{$\begin{array}{c}\begin{array}{c}\text { 2-year-recurrence, } \\
\text { 30-minute-duration rainfall }\end{array} \\
27 \mathrm{~mm}\end{array}$}} & \multirow{2}{*}{\multicolumn{3}{|c|}{$\begin{array}{c}\begin{array}{c}10 \text {-year-recurrence, } \\
\text { 30-minute-duration rainfall }\end{array} \\
42 \mathrm{~mm}\end{array}$}} & \multirow{2}{*}{\multicolumn{3}{|c|}{$\begin{array}{c}\begin{array}{c}\text { 25-year-recurrence, } \\
\text { 30-minute-duration rainfall }\end{array} \\
51 \mathrm{~mm}\end{array}$}} \\
\hline & & & & & & & & & & & & \\
\hline & & & & $\begin{array}{l}\text { Prob- } \\
\text { ability } \\
(\%)\end{array}$ & $\begin{array}{l}\text { Volume } \\
\left(\mathrm{m}^{3}\right)\end{array}$ & $\begin{array}{c}\text { Combined } \\
\text { hazard } \\
\text { ranking }\end{array}$ & $\begin{array}{l}\text { Prob- } \\
\text { ability } \\
(\%)\end{array}$ & $\begin{array}{l}\text { Volume } \\
\left(\mathrm{m}^{3}\right)\end{array}$ & $\begin{array}{l}\text { Combined } \\
\text { hazard } \\
\text { ranking }\end{array}$ & $\begin{array}{l}\text { Prob- } \\
\text { ability } \\
(\%)\end{array}$ & $\begin{array}{l}\text { Volume } \\
\left(\mathrm{m}^{3}\right)\end{array}$ & $\begin{array}{l}\text { Combined } \\
\text { hazard } \\
\text { ranking }\end{array}$ \\
\hline 30 & Mineral Farms Canyon & 84.2 & 1.91 & 86 & 22,134 & 4 & 98 & 32,234 & 4 & 99 & 38,955 & 4 \\
\hline 31 & Schoolhouse Canyon & 75.1 & 1.35 & 94 & 17,358 & 4 & 99 & 25,278 & 4 & 100 & 30,549 & 4 \\
\hline 32 & Nolten Canyon & 86.3 & 1.18 & 96 & 16,101 & 4 & 100 & 23,448 & 4 & 100 & 28,337 & 4 \\
\hline 33 & Philadelphia Canyon & 57.6 & 7.84 & 87 & $>100,000$ & 5 & 98 & $>100,000$ & 5 & 100 & $>100,000$ & 5 \\
\hline 34 & Jackson Canyon & 77.3 & 1.45 & 91 & 17,698 & 4 & 99 & 25,774 & 4 & 100 & 31,148 & 4 \\
\hline 35 & Mills Canyon & 81.2 & 4.69 & 97 & 78,221 & 4 & 100 & $>100,000$ & 5 & 100 & $>100,000$ & 5 \\
\hline 36 & Crocket Canyon & 37.6 & 1.51 & 73 & 11,882 & 3 & 96 & 17,304 & 4 & 99 & 20,912 & 4 \\
\hline 37 & Peters Canyon & 47.3 & 2.17 & 62 & 18,456 & 3 & 94 & 26,878 & 4 & 98 & 32,482 & 4 \\
\hline 38 & Angus Canyon & 45.9 & 0.75 & 24 & 6,028 & 2 & 73 & 8,778 & 3 & 91 & 10,609 & 4 \\
\hline 39 & Unnamed tributary to Bonito Creek & 54.2 & 0.61 & 41 & 5,867 & 2 & 86 & 8,544 & 3 & 96 & 10,326 & 4 \\
\hline 40 & Unnamed tributary to Bonito Creek & 37.5 & 1.14 & $<20$ & 6,723 & 1 & 47 & 9,791 & 2 & 76 & 11,833 & 3 \\
\hline 41 & Unnamed tributary to Bonito Creek & 25.9 & 1.02 & $<20$ & $<5,000$ & 1 & $<20$ & 5,865 & 1 & 42 & 7,088 & 2 \\
\hline 42 & Unnamed tributary to Bonito Creek & 14.8 & 0.41 & $<20$ & $<5,000$ & 1 & $<20$ & $<5,000$ & 1 & 36 & $<5,000$ & 2 \\
\hline 43 & Unnamed tributary to Little Creek & 0.4 & 1.71 & $<20$ & $<5,000$ & 1 & 26 & $<5,000$ & 1 & 55 & $<5,000$ & 2 \\
\hline 44 & Vickers Canyon & 39.7 & 1.18 & 73 & 9,708 & 3 & 96 & 14,139 & 4 & 99 & 17,087 & 4 \\
\hline 45 & Little Creek & 61.7 & 3.44 & 71 & 36,172 & 3 & 96 & 52,679 & 4 & 99 & 63,663 & 4 \\
\hline 46 & Phillips Canyon & 48.5 & 1.95 & $<20$ & 13,139 & 2 & 55 & 19,134 & 3 & 82 & 23,124 & 4 \\
\hline 47 & Flume Canyon & 66.4 & 1.42 & 43 & 13,905 & 3 & 87 & 20,251 & 4 & 96 & 24,473 & 4 \\
\hline 48 & Hubbard Canyon & 62.3 & 1.91 & 28 & 16,437 & 2 & 77 & 23,938 & 3 & 92 & 28,929 & 4 \\
\hline 49 & Upper Eagle Creek & 94.5 & 4.46 & 80 & 53,067 & 3 & 97 & 77,284 & 4 & 99 & 93,398 & 4 \\
\hline 50 & Unnamed tributary to Eagle Creek & 92.3 & 1.20 & 96 & 16,951 & 4 & 100 & 24,686 & 4 & 100 & 29,833 & 4 \\
\hline 51 & Telephone Canyon & 90.7 & 1.00 & 97 & 14,365 & 4 & 100 & 20,921 & 4 & 100 & 25,283 & 4 \\
\hline 52 & Johnson Canyon & 80.5 & 1.15 & 57 & 12,606 & 3 & 92 & 18,359 & 4 & 98 & 22,187 & 4 \\
\hline 53 & Carlton Canyon & 83.8 & 1.84 & $<20$ & 13,979 & 2 & 48 & 20,358 & 3 & 77 & 24,603 & 3 \\
\hline 54 & $\begin{array}{l}\text { Unnamed tributary to South Fork Eagle } \\
\text { Creek }\end{array}$ & 88.0 & 1.04 & 88 & 13,443 & 4 & 98 & 19,577 & 4 & 100 & 23,659 & 4 \\
\hline 55 & $\begin{array}{l}\text { Unnamed tributary to North Fork Rio } \\
\text { Ruidoso }\end{array}$ & 87.1 & 1.19 & 76 & 13,838 & 3 & 97 & 20,153 & 4 & 99 & 24,355 & 4 \\
\hline 56 & Upper North Fork Rio Ruidoso & 70.4 & 5.79 & 39 & 45,014 & 2 & 85 & 65,555 & 4 & 95 & 79,224 & 4 \\
\hline
\end{tabular}


Rio Bonito and parts of tributaries north and south of Rio Bonito from Big Bear and George Washington Canyons and east to approximately Mills Creek and Philadelphia Canyon. Also included are parts of North Fork Eagle Creek, Little Creek, and North Fork Rio Ruidoso in the southern burn area and Magado Creek in the northeastern burn area (pl. 1 and fig. 1). The drainage basins selected for delineation included the moderate- and high-severity burn areas where slope, drainage basin configuration, and topographic setting indicated susceptibility to debris-flow processes or areas where proximity to development indicated a vulnerability to hazards presented by debris flows.

Postwildfire debris flows in the intermountain Western United States often occur in response to short-duration, high-intensity rainfall events. Cannon and others (2008) found that most debris flows occur in response to storms with short recurrence intervals (from 2 to 10 years), and Kean and others (2011) demonstrated that intense rain in periods of less than 30 minutes generated postwildfire debris flows. To characterize the effects of these rainfall conditions, the probability that a drainage basin could produce debris flows and the volume of a possible debris flow at the basin outlet were estimated for three design storms: (1) a 2-yearrecurrence, 30-minute-duration rainfall of 27 millimeters $(\mathrm{mm})(1 \mathrm{inch})(\mathrm{a} 50$ percent chance of occurrence in any given year); (2) a 10-year-recurrence, 30-minute-duration rainfall of $42 \mathrm{~mm}$ (1.7 inches) (a 10 percent chance of occurrence in any given year); and (3) a 25-year-recurrence, 30-minute-duration rainfall of $51 \mathrm{~mm}$ ( 2 inches) (a 4 percent chance of occurrence in any given year). Precipitation data were from Bonnin and others (2006), based on extrapolated isohyetal values for a midelevation location within the burn area.

Results for the three design storms are presented in table 1. Results for the 2-year-recurrence rainfall (presented in pls. 1 through 3) were chosen for the map presentation because the 2-year event exhibited the best differentiation among the drainage basins and best highlighted the highest probability response drainage basins. For the 10- and 25-year-recurrence rainfalls, a greater percentage of the drainage basins fall into the higher probability intervals. An uneven distribution and intensity of rainfall over the burn area may result in varying response probabilities in varying parts of the burn area.

\section{Debris-Flow Hazard Assessment}

The hazards of debris flows from drainage basins burned by the Little Bear Fire were assessed by estimating the probability of occurrence, by estimating the volume of potential debris flows, and by combining the probability and volume into a relative hazard ranking.

\section{Debris-Flow Probability Estimates}

In response to the 2-year-recurrence rainfall, modeling indicated that 22 drainage basins $(17,19-35,49-51$, and 54) have high probabilities of debris-flow occurrence (greater than or equal to 80 percent) (pl. 1 and table 1). For the 10 -year-recurrence rainfall, an additional 13 drainage basins $(1,5,6,13,36,37,39,44,45,47,52,55$, and 56) have high probabilities of debris-flow occurrence, and for the 25-yearrecurrence rainfall, an additional 10 drainage basins $(4,7$, $8,12,14,16,18,38,46$, and 48$)$, representing together 80 percent of the total, have high probabilities of debris-flow occurrence (table 1).

Basins with a high probability of debris-flow occurrence in response to the 2-year-recurrence rainfall were primarily located in the central part of the burn area, including tributaries to South Fork Rio Bonito (22); Big Bear (17), Dark Betsy (21), Wallsmith (24) and Roadmaker (25) Canyons above Bonito Lake; and tributary canyons north and south of Rio Bonito from Bonito Lake to Mills Creek (35) and Philadelphia Canyon (33) (pl. 1). Selected tributaries on North Fork Eagle Creek were also modeled as having high probabilities of debris-flow occurrence in response to the 2-year-recurrence rainfall (pl. 1). Debris flows generated from burned drainage basins may directly affect Bonito Lake and buildings and infrastructure along Rio Bonito, as well as parts of North Fork Eagle Creek and the Villa Madonna area.

Stream segment analysis identifies stream segments within a basin with a higher or lower probability of debrisflow occurrence than predicted at the basin outlet. For example, both South Fork Rio Bonito (22) and Big Bear Canyon (17) have a high probability of debris flow throughout much of the drainage basins but contain stream segments with a lower probability of debris flows (pl. 1). Philadelphia Canyon (33) was modeled as having primarily a low probability of debris flows in the upper reaches but increasing to an $80-90$ percent debris-flow probability at the basin outlet. In contrast, North Fork Eagle Creek (49-53) and Little Creek (45) contain high-probability segments within parts of the upper reaches but probabilities decrease abruptly for stream segments near the basin outlets. Stream segment analysis along North Fork Eagle Creek indicates a high probability of debris flows from the outlet of Upper Eagle Creek (49) to below the confluence with Carlton Canyon (53), where the probability decreases to $60-79$ percent.

The location of observed postwildfire debris flows supports the probability analysis. On June 22, 2012, precipitation produced debris flows and mud flows within the burn area (Weldon, 2012). About $13 \mathrm{~mm}$ (0.5 inches) of precipitation fell in 1 hour, an approximately 1 -yearrecurrence rainfall (Bonnin and others, 2006), with more than $25 \mathrm{~mm}$ (1 inch) of total precipitation observed. Evidence of debris flows was identified at three locations in response to the June 22 storm, at Tanbark (18), George Washington (20), and Anan (27) Canyons (K. Weldon, U.S. Department of Agriculture Forest Service, written commun., 2012) (pl. 1). Debris flows and large amounts of sediment movement were also noted at other locations throughout the summer, although the amount and intensity of rainfall associated with this sediment movement are not known. These locations include the mouth of Spring Canyon (29) (pl. 1 and fig. 2) 


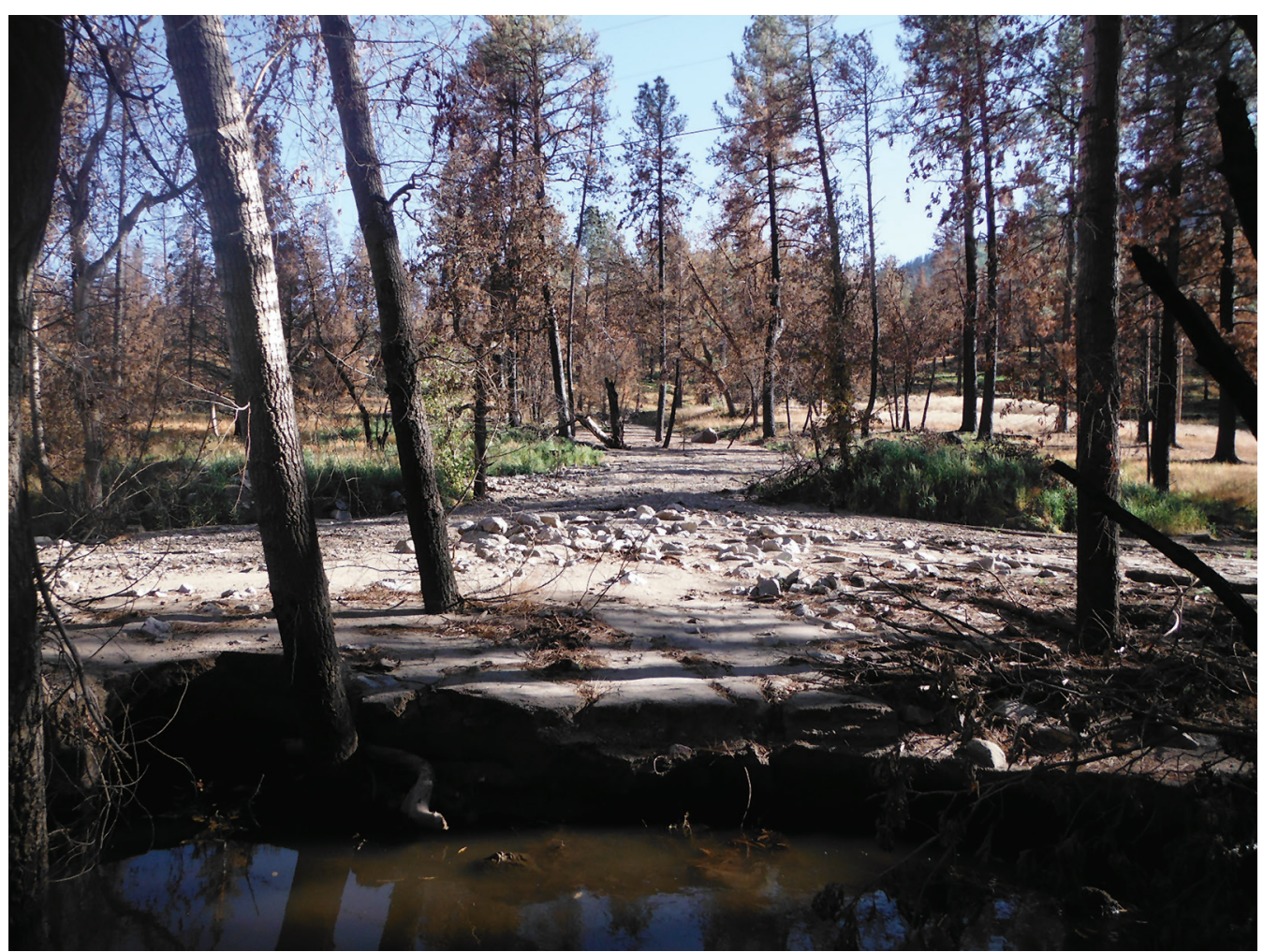

Figure 2. Sediment deposition at the mouth of Spring Canyon following the Little Bear Fire, south-central New Mexico, summer 2012. Rio Bonito is in the foreground.

(J. Snyder, U.S. Department of Agriculture Forest Service, written commun., 2012) and North Fork Eagle Creek, where transported sediment impinged on cabins and buried a USGS streamgage (pl. 1 and fig. 3). George Washington and Spring Canyons and the upper parts of North Fork Eagle Creek (49 and 50) were all modeled as having greater than 80 percent probability of debris flows in response to the 2-year-recurrence rainfall throughout the drainage basins. The stream segment where there was debris-flow evidence in Anan Canyon (27) was modeled with 60-79 percent probability of debris flows in response to the 2-year-recurrence rainfall (pl. 1 and table 1). The upper parts of Tanbark Canyon (18) are outside of the burn perimeter, and much of the area inside the burn perimeter within Tanbark Canyon was classified as low-severity burn. Parts along the eastern edge of Tanbark Canyon basin, where debris-flow deposits were identified, however, were classified as moderate- to high-severity burn, and the stream segment analysis modeled these side tributaries as having a 40-79 percent probability of debris-flow occurrence. The debris-flow analysis and location of debris-flow deposits within Tanbark and Anan Canyons demonstrate the utility of the continuousparameterization technique in identifying and highlighting high-probability response areas within a basin with variable burn intensity.

High debris-flow probabilities reflect the combined effects of drainage basins being nearly completely burned at high and moderate severities and having steep slopes. The localized nature of the debris flows reported in response to the June 22 storm reflects, in part, the localized nature of the summer storm cells compared to the assumption of uniform precipitation over the entire burn area, the conservative assumption on which the model was based.

\section{Debris-Flow Volume Estimates}

The debris-flow volumes estimated in this assessment are independent of the estimated debris-flow probabilities. As a result, drainage basins with high predicted debris-flow probabilities represent varying degrees of hazard to areas downstream, depending on the predicted volume of material mobilized in a debris flow. Estimated debris-flow volumes can vary by stream segment, as indicated by changes in stream segment color along a drainage network (pl. 2). The stream segment analysis estimates the volume of debris-flow material mobilized above a given analysis point but does not account for potential within-basin deposition of mobilized material. Basin color on plate 2 indicates the estimated debris-flow volume at the basin outlet. Estimated debris-flow volumes ranged from less than 5,000 cubic meters $\left(\mathrm{m}^{3}\right)$ to greater than $100,000 \mathrm{~m}^{3}$ for the modeled storms (table 1). Drainage basins with estimated debris-flow volumes greater than 100,000 $\mathrm{m}^{3}$ included Bear Creek (17), South Fork Rio Bonito (22), Anan Canyon (27), and Philadelphia Canyon (33) for the 2-year-recurrence rainfall (pl. 2) and an additional basin, 

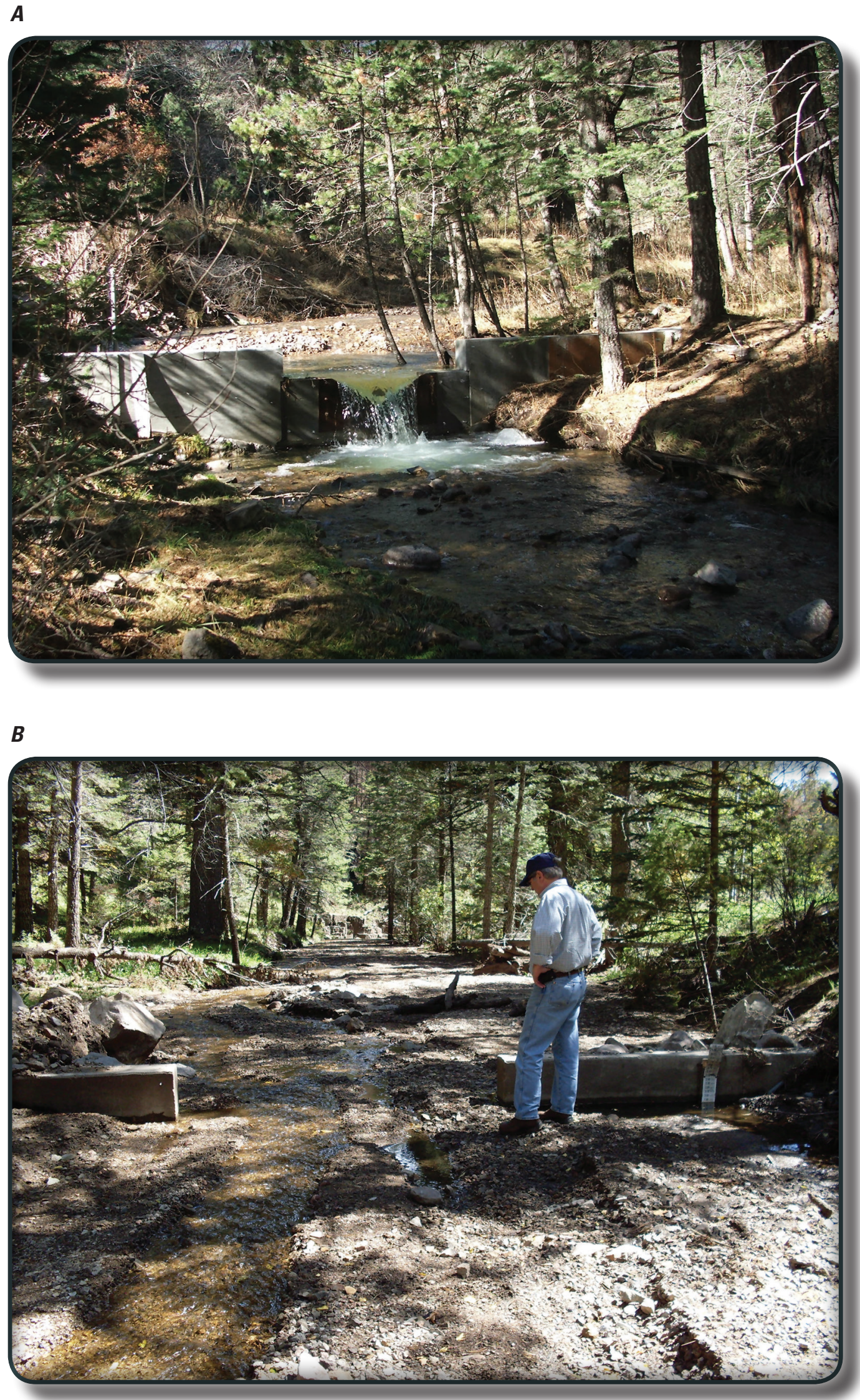

Figure 3. North Fork Eagle Creek near Alto, New Mexico (08387550), streamgage before and after the Little Bear Fire in 2012. A, View from below weir, 2007 (photograph by Patrick Swift). B, View from above weir, 2013. 
Mills Canyon (35), for the 10-year and 25-year-recurrence rainfalls. Drainage basins with estimated debris-flow volumes greater than $50,000 \mathrm{~m}^{3}$ for the 2-year-recurrence rainfall also included Mills Canyon (35) and Upper Eagle Creek (49), with additional drainage basins Dark Betsy Canyon (21), Bluefront Canyon (23), Littleton Canyon (26), Little Creek (45), and Upper North Fork Rio Ruidoso (46) (pl. 2), for the 10-year-recurrence rainfall and Upper Bonito Creek/Aspen Canyon (12), Little Bear Canyon (13), Tanbark Canyon (18), Wallsmith Canyon (24), and Roadmaker Canyon (25) for the 25-year-recurrence rainfall. Stream segment analysis indicated that South Fork Rio Bonito (22) has a high estimated debris-flow volume along much of the main stem, with lesser volumes estimated from the upper reaches and side channels. In Bear Creek (17), Anan Canyon (27), and Philadelphia Canyon (33), the highest estimated debris-flow volume is confined to the lower reach of the drainage basins, with decreasing estimated volumes headward in the drainage basins and in the side channels. North Fork Eagle Creek has high estimates of debris-flow volume in the lower reaches of Upper Eagle Creek (49), but the highest volumes were estimated for North Fork Eagle Creek below Telegraph Canyon (51). It is not known if the estimated volumes of material are sufficient to dam watercourses or cause flooding, which could affect resources downstream from the evaluated drainage basins.

\section{Combined Relative Debris-Flow Hazard Rankings}

Combined probability and volume relative hazard rankings of postwildfire debris flows were produced by summing the estimated probability and volume ranking to illustrate those areas with the highest potential occurrence of debris flows with the largest volumes. Rankings are shown for the 2-year-recurrence rainfall (pl. 3). The highest combined hazard ranking is predicted for four drainage basins, Bear Creek (17), South Fork Rio Bonito (22), Anan Canyon (27), and Philadelphia Canyon (33) for the 2-year-recurrence rainfall (table 1). With the second highest combined hazard ranking, an additional 17 drainage basins (19-21, 23-26, $28-32,34,35,50,51$, and 54) are included. For the 10-yearrecurrence rainfall, those same four drainage basins plus Mills Canyon (35) were modeled with the highest combined hazard ranking. Including the second highest combined hazard ranking category adds drainage basins $1,5,6,13,19-21$, $23-26,28-32,34,36,37,44,45,47,49-52$, and 54-56. For the 25 -year-recurrence rainfall, an additional 10 drainage basins $(4,8,12,14,16,18,38,39,46$, and 48$)$, representing together 79 percent of the total, were modeled with the two highest combined hazard rankings (table 1).

Stream segment analysis indicated a relative hazard ranking at the two highest categories over most of the central Rio Bonito drainage basin. Little Bear Canyon (12) is generally ranked at a medium hazard but has segments of higher hazard ranking in the upper basin. Stream segments in Magado Creek drainage basin (1-9) were modeled over the range of established rankings, with high rankings in the upper reaches of drainage basins 4-7. Within the southern part of the burn area, high relative hazard rankings were found in parts of most drainage basins, including Little Creek (45), North Fork Eagle Creek (49-52), and North Fork Rio Ruidoso (56). North Fork Eagle Creek from Telegraph Canyon (51) to below Carlton Canyon (53) is the only segment in the southern burn area modeled with the highest relative hazard ranking.

\section{Limitations of Hazard Assessments}

This assessment provides estimates of debris-flow probability, volume, and combined relative hazard ranking in response to 30-minute-duration design storms with 2-, $10-$, and 25-year-recurrence probabilities for drainage basins burned by the Little Bear Fire. The term \%SG30, the percent of the drainage basin area with slopes equal to or greater than 30 percent, is a factor in both the probability model and the volume model. In 70 percent of the 56 drainage basins modeled, more than 50 percent of the basin area has a slope greater than 30 percent (table 1). The percentage of basin area with a greater than 30 percent slope ranges from 0.2 to 94.5 percent, with a median of 75.1 percent. The drainage basin with the median value is Schoolhouse Canyon (31), and the drainage basin with the highest value is Upper Eagle Creek (49). Because of the high percentage of area with steep slopes in many of the delineated drainage basins within the burn area, the slope factor is an important contributor to both the probability estimates and the volume estimates of debris flows within the Little Bear Fire burn area.

The probability of debris flows increases with increasing recurrence interval (lower probability of occurrence but higher intensity) design storm. The probability of debris flows in response to the 2-year design storm is high (greater than 80 percent) for 39 percent of the 56 drainage basins modeled; the probability of debris flows in response to the 25 -year design storm is high for 80 percent of the modeled drainage basins. For debris-flow volume, estimated debris-flow volume is greater than $100,000 \mathrm{~m}^{3}$ in response to the 2-year design storm in 7 percent of the modeled drainage basins; 9 percent of the drainage basins are included in the greater than $100,000 \mathrm{~m}^{3}$ category for both the 10-year and the 25-year design storms. Drainage basins in the greater than $100,000 \mathrm{~m}^{3}$ volume category were also modeled with the highest combined hazard ranking. The small increase in the number of drainage basins with the highest combined hazard ranking with increasing storm intensity reflects the fact that, while a large percentage of drainage basins may potentially produce debris flows, the estimated volume of material associated with these events is limited. This statement does not imply that debris flows of any size do not have the potential to cause damage but provides a method for evaluating areas within the burn area with greater potential hazard from a given magnitude rain event. Larger, less frequent storms (for example, a 50-year-recurrence 
rainfall) are likely to produce larger debris flows, and smaller, more frequent storms (for example, a 1-year-recurrence rainfall) could also trigger debris flows, but they would likely be smaller. Higher probabilities of debris flows than those shown on plate 1 may exist within any part of the drainage basins. Because not all rainstorms will be large enough to affect the entire burn area, debris flows may not be produced from all drainage basins during a given storm.

It is important to note that the maps shown in plates 1, 2 , and 3 do not identify those areas that can be affected by debris flows as the material moves downstream from the basin outlets (Cannon and others, 2010). Additionally, further investigation is needed to assess the potential for debris flows to affect structures at, or downstream from, basin outlets and to increase the threat of flooding downstream by damaging or blocking bridges or flood-mitigation structures.

The variables included in the models and used in this assessment are considered to directly affect debris-flow generation in the intermountain Western United States. Conditions other than those used in the models (for example, the amount of sediment stored in a canyon) could also affect debris-flow production. Data necessary to evaluate such effects, however, are not readily available.

The potential for debris-flow activity decreases with time as revegetation stabilizes hillslopes and the supply of erodible material decreases in the canyons. If dry conditions prevent sufficient regrowth of vegetation, however, this recovery period may be longer. In contrast, if rainfall events for the first year are frequent but mild, recovery and stabilization of soil with vegetation may occur rapidly and diminish debrisflow hazards the following year. After the Little Bear Fire, approximately $36 \mathrm{~km}^{2}$ (8,970 acres) of land with moderate- to high-severity burn were treated by seeding, $41 \mathrm{~km}^{2}(10,241$ acres) were treated by using seed with straw mulch, and about $0.7 \mathrm{~km}^{2}$ on the Mescalero Apache Reservation were treated by mulching with straw (Gary Ziehe, U.S. Department of Agriculture Forest Service, oral commun., 2012). Mulching is expected to reduce the probability and volume of erosion in these areas compared to pretreatment levels (Groen and Woods, 2008; Robichaud and others, 2010). The debris-flow analysis is based on initial postwildfire conditions and does not account for potential mitigating effects of postfire treatments. The analysis does serve to highlight, especially by the stream segment analysis, those parts of a basin with an increased debris-flow hazard ranking based on physical characteristics. The assessment given herein is estimated to be applicable for $2-3$ years after the fire, depending on precipitation distribution (Cannon and others, 2010).

The maps in this report may be used to prioritize areas where emergency erosion mitigation or other protective measures may be needed prior to rainstorms within these drainage basins, their outlets, or areas downstream from these drainage basins within the 2- to 3-year period of vulnerability following the Little Bear Fire. This assessment evaluates only postwildfire debris flows and does not consider hazards associated with flash floods; such hazards may remain for many years after a fire.
This work is preliminary and is subject to revision. It is being provided because of the need for timely best science information. The assessment herein is provided on the condition that neither the USGS nor the U.S. Government may be held liable for any damages resulting from the authorized or unauthorized use of the assessment.

\section{Summary}

In June 2012, the Little Bear Fire burned approximately 179 square kilometers $\left(\mathrm{km}^{2}\right)(44,330$ acres $)$ in south-central New Mexico, including about $143 \mathrm{~km}^{2}$ (35,300 acres) of National Forest System lands of the Lincoln National Forest. Within the Lincoln National Forest, about $72 \mathrm{~km}^{2}(17,664$ acres) of the White Mountain Wilderness were burned. The burn area also included about $34 \mathrm{~km}^{2}(8,500$ acres) of private lands. Burn severity was high or moderate on 53 percent of the burn area, which is characterized by very steep and rugged mountains and interspersed valleys with vegetation ranging from pinyon-juniper (Pinus and Juniperus spp.) scrub at an elevation of about 2,000 meters $(6,500$ feet) to mixed conifer forests and alpine grasslands at an elevation higher than 3,600 meters (11,900 feet).

High- to moderate-severity burn areas were identified in the headwaters of drainage basins that drain into the Rio Bonito which subsequently flows through Bonito Lake. Bonito Lake provides 60 percent of the municipal water for the City of Alamogordo and Holloman Air Force Base. High- to moderate-severity burn areas were also identified in parts of Little Creek drainage basin, in the vicinity of the community of Villa Madonna, and in parts of North Fork Eagle Creek drainage basin, which includes the Village of Ruidoso municipal wells and a group of historic U.S. Department of Agriculture (USDA) Forest Service cabins. Alto Reservoir, located on Eagle Creek downstream from the burn area, provides a portion of the Village of Ruidoso municipal water supply. Drainage basins along Highway 532 above Alto Reservoir and parts of Magado Creek drainage basin in the northeastern part of the burn area were also affected. The area burned by the Little Bear Fire is at risk of substantial postwildfire erosion, such as that caused by debris flows and flash floods.

A postwildfire debris-flow hazard assessment of the area burned by the Little Bear Fire was performed by the U.S. Geological Survey in cooperation with the USDA Forest Service, Lincoln National Forest. A set of two empirical hazard-assessment models developed from data collected in recently burned drainage basins throughout the intermountain Western United States was used to estimate the probability of occurrence and volume of debris flows along the burn area drainage network and for selected drainage basins within the Little Bear Fire burn area in response to 30-minute-duration design storms of 2-, 10-, and 25-year-recurrence rainfall. The models incorporate measures of areal burn extent and severity, topography, soils, and storm rainfall intensity to estimate the probability and volume of debris flows following the fire. 
The probability of debris flows in response to the 2-year design storm is high (greater than 80 percent) for 39 percent of the 56 drainage basins modeled; the probability of debris flows in response to the 25 -year design storm is high for 80 percent of the modeled drainage basins. For debris-flow volume, estimated debris-flow volume is greater than 100,000 cubic meters $\left(\mathrm{m}^{3}\right)$ in response to the 2-year design storm in 7 percent of the modeled drainage basins; 9 percent of the drainage basins are included in the greater than $100,000 \mathrm{~m}^{3}$ category for both the 10-year and the 25-year design storms. Drainage basins in the greater than $100,000 \mathrm{~m}^{3}$ volume category also were also modeled with the highest combined hazard ranking.

The debris-flow analysis is based on initial postfire conditions and does not account for potential mitigating effects of postfire treatments such as mulching and seeding carried out by the USDA Forest Service following the Little Bear Fire. The analysis does serve to highlight, especially by the stream segment analysis, those parts of a basin with an increased debris-flow hazard ranking based on physical characteristics. The maps presented herein may be used to prioritize areas where emergency erosion mitigation or other protective measures may be needed prior to rainstorms within these drainage basins, their outlets, or areas downstream from these drainage basins within the 2- to 3-year period of vulnerability. Variability in climatic conditions following a wildfire, such as an extended period that is wetter or dryer than normal, could result in variability in this period of vulnerability.

This work is preliminary and is subject to revision. It is being provided because of the need for timely best science information. The assessment herein is provided on the condition that neither the U.S. Geological Survey nor the U.S. Government may be held liable for any damages resulting from the authorized or unauthorized use of the assessment.

\section{References Cited}

Bonnin, G.M., Martin, Deborah, Lin, Binghang, Parzybok, Tye, Yekta, Michael, and Riley, David, 2006, Precipitationfrequency atlas of the United States: Silver Spring, Md., National Weather Service, National Oceanic and Atmospheric Administration (NOAA) atlas 14, v. 1, version 5, accessed November 14, 2012, at http://hdsc.nws.noaa. gov/hdsc/pfds/.

Cannon, S.H., and Gartner, J.E., 2005, Wildfire-related debris flow from a hazards perspective, chap. 15 of Jakob, Matthias, and Hungr, Oldrich, eds., Debris-flow hazards and related phenomena: Chichester, U.K., Springer-Praxis Books in Geophysical Sciences, p. 321-344.

Cannon, S.H., Gartner, J.E., and Michael, J.A., 2007, Methods for the emergency assessment of debris-flow hazards from basins burned by the fires of 2007, southern California: U.S. Geological Survey Open-File Report 2007-1384, 10 p. (Also available at http://pubs.usgs.gov/of/2007/1384/.)
Cannon, S.H., Gartner, J.E., Rupert, M.G., Michael, J.A., Rea, A.H., and Parrett, Charles, 2010, Predicting the probability and volume of postwildfire debris flows in the intermountain Western United States: Geological Society of America Bulletin, v. 122, p. 127-144.

Cannon, S.H., Gartner, J.E., Wilson, R.C., and Laber, J.L., 2008, Storm rainfall conditions for floods and debris flows from recently burned areas in southwestern Colorado and southern California: Geomorphology, v. 96, p. 250-269.

DeBano, L.F., 1981, Water repellant soil-A state-of-the-art: Berkeley, Calif., U.S. Department of Agriculture, Forest Service, Pacific Southwest Forest and Range Experiment Station, General Technical Report PSW-46, 21 p.

DeGraff, J.V., Wagner, D.L., Gallegos, A.J., DeRose, M.B., Shannon, Casey, and Ellsworth, Todd, 2011, The remarkable occurrence of large rainfall-induced debris flows at two different locations on July 12, 2008, Sierra Nevada, California: Landslides, v. 8, no. 2, p. 343-353.

Doerr, S.H., Shakesby, R.A., and Walsh, R.P.D., 2000, Soil water repellency-Its causes, characteristics and hydrogeomorphological significance: Earth-Science Reviews, v. 15 , p. 33-65.

Environmental Systems Research Institute, Inc., 2009, ArcGIS v. 9.3: Redlands, Calif., Environmental Systems Research Institute, Inc.

Gesch, D.B., Oimoen, M.J., Greenlee, S.K., Nelson, Charles, Steuck, Michael, and Tyler, D.J., 2002, The National Elevation Dataset: Photogrammetric Engineering and Remote Sensing, v. 68, no. 1, p. 5-11.

Green, G.N., and Jones, G.E., 1997, The digital geologic map of New Mexico in ARC/INFO format: U.S. Geological Survey Open-File Report 97-0052, 9 p. (Also available at http://pubs.usgs.gov/of/1997/ofr-97-0052/.)

Groen, A.H., and Woods, S.W., 2008, Effectiveness of aerial seeding and straw mulch for reducing post-wildfire erosion, north-western Montana, USA: International Journal of Wildland Fire, v. 17, p. 559-571.

Helsel, D.R., and Hirsch, R.M., 2002, Statistical methods in water resources, chap. A3 of book 4, Hydrologic analysis and interpretation: U.S. Geological Survey Techniques of Water-Resources Investigations, $522 \mathrm{p}$. (Also available at http://pubs.usgs.gov/twri/twri4a3/.)

Hill, Jennifer, Koehler, Nori, and Kiesow, Micah, 2012, Ski Apache Little Bear Wildfire BAER resource report, Lincoln National Forest, soil report: U.S. Department of Agriculture, Forest Service, Southwestern Region, Lincoln National Forest, $10 \mathrm{p}$. 
Kean, J.W., Staley, D.M., and Cannon, S.H., 2011, In situ measurements of post-fire debris flows in southern California-Comparisons of the timing and magnitude of 24 debris-flow events with rainfall and soil moisture conditions: Journal of Geophysical Research, doi:10.1029/2011JF002005.

Letey, John., 2001, Causes and consequences of fire-induced soil water repellency: Hydrological Processes, v. 15, p. 2867-2875.

Matherne, A.M., Myers, N.C., and McCoy, K.J., 2010, Hydrology of Eagle Creek Basin and effects of groundwater pumping on streamflow, 1969-2009: U.S. Geological Survey Scientific Investigations Report 2010-5205, 73 p. (Also available at http://pubs.usgs.gov/sir/2010/5205/.)

Melton, M.A., 1965, The geomorphic and paleoclimatic significance of alluvial deposits in southern Arizona: Journal of Geology, v. 73, p. 1-38.

Moody, J.A., and Martin, D.A., 2001a, Hydrologic and sedimentologic response of two burned watersheds in Colorado: U.S. Geological Survey Water-Resources Investigations Report 01-4122, 138 p. (Also available at http://pubs.usgs.gov/wri/2001/4122/report.pdf.)

Moody, J.A., and Martin, D.A., 2001b, Initial hydrologic and geomorphic response following a wildfire in the Colorado Front Range: Earth Surface Processes and Landforms, v. 26, p. 1049-1070.

New Mexico Environment Department, 2013, Surface Water Quality Bureau water quality standards, Outstanding National Resource Waters: accessed January 9, 2013, at http://www.nmenv.state.nm.us/swqb/ONRW/.

Payne, Brian, and Beach, Ryan, 2012, Little Bear BAER assessment engineering report: U.S. Department of Agriculture, Forest Service, Southwestern Region, Lincoln National Forest, $34 \mathrm{p}$.

Rawling, G.C., 2011, Geology of the Ruidoso area, Lincoln and Otero Counties, New Mexico: New Mexico Bureau of Geology and Mineral Resources Open-File Report OFR507, scale 1:24,000.

Rivix, LLC, 2012, RiverTools 3.0.3: Broomfield, Colo., Rivix, LLC, accessed July 10, 2012, at http://rivix.com.

Robichaud, P.R., Ashmun, L.E., and Sims, B.D., 2010, Postfire treatment effectiveness for hillslope stabilization: Fort Collins, Colo., U.S. Department of Agriculture, Forest Service, Rocky Mountain Research Station, General Technical Report RMRS-GTR-240, 62 p.

Romkens, M.J.M., Prasad, S.N., and Whisler, F.D., 1990, Surface sealing and infiltration, chap. 5 of Anderson, M.G., and Burt, T.P., eds., Process studies in hillslope hydrology: New York, John Wiley and Sons, p. 127-172.
Schwartz, G.E., and Alexander, R.B., 1995, Soils data for the conterminous United States derived from the NRCS State Soil Geographic (STATSGO) Database: U.S. Geological Survey Open-File Report 95-449, accessed July 2011 at http://water.usgs.gov/lookup/getspatial?/ussoils.

Snyder, Jim, Banks, April, Brown, Paul, and Lovely, Collis, 2012, 2012 Little Bear Fire, BAER hydrology report: U.S. Department of Agriculture, Forest Service, Southwestern Region, Lincoln National Forest, $20 \mathrm{p}$.

Thompson, T.B., 1972, Sierra Blanca Igneous Complex, New Mexico: Geologic Society of America Bulletin, v. 83, p. 2341-2356.

Tillery, A.C., Darr, M.J., Cannon, S.H., and Michael, J.A., 2011a, Postwildfire debris flow hazard assessment for the area burned by the 2011 Track Fire in northeastern New Mexico and southeastern Colorado: U.S. Geological Survey Open-File Report 2011-1257, 9 p. (Also available at http://pubs.usgs.gov/of/2011/1257/.)

Tillery, A.C., Darr, M.J., Cannon, S.H., and Michael, J.A., 2011b, Postwildfire preliminary debris flow hazard assessment for the area burned by the 2011 Las Conchas Fire in north-central New Mexico: U.S. Geological Survey Open-File Report 2011-1308, 11 p. (Also available at http:// pubs.usgs.gov/of/2011/1308/.)

Tillery, A.C., Matherne, A.M., and Verdin K.L., 2012, Estimated probability of postwildfire debris flows in the 2012 Whitewater-Baldy Fire burn area, southwestern New Mexico: U.S. Geological Survey Open-File Report 20121188, 11 p., 3 pls. (Also available at http://pubs.usgs.gov/ of $/ 2012 / 1188 /$.

U.S. Geological Survey, 2011, Seamless Data Warehouse, National Elevation Dataset 1/9 arc-second: accessed July 10, 2012, at http://nationalmap.gov/viewer.html.

Verdin, K.L., and Greenlee, S.K., 2003, Continuous basin parameterization using EDNA, in 2003 ESRI User's Conference, San Diego, Calif., July 7-11, 2003, Proceedings: Redlands, Calif., Environmental Systems Research Institute, accessed June 25, 2012, at http:/gis.esri.com/library/userconf/proc03/p0617.pdf.

Verdin, K.L., and Worstell, B.B., 2008, A fully distributed implementation of mean annual streamflow regional regression equations: Journal of the American Water Resources Association, v. 44, p. 1537-1547, doi: 10.1111/j.1752-1688.2008.00258.x.

Weldon, Kevin, 2012, Little Bear Wildfire, BAER resource report, Lincoln National Forest, Geology Resource Report: U.S. Department of Agriculture, Forest Service, Southwestern Region, Lincoln National Forest, 10 p. 
Wells, H.G., 1987, The effects of fire on the generation of debris flows in southern California, in Costa, J.E., and Wieczorek, G.F., eds., Debris flows/avalanches-Process, recognition, and mitigation: Geological Society of America, Reviews in Engineering Geology, v. 7, p. 105-114.
Woods, S.W., Birkas, Anna., and Ahl, R.S., 2006, Spatial variability of soil hydrophobicity after wildfires in Montana and Colorado: Geomorphology, v. 86, p. 465-479. 



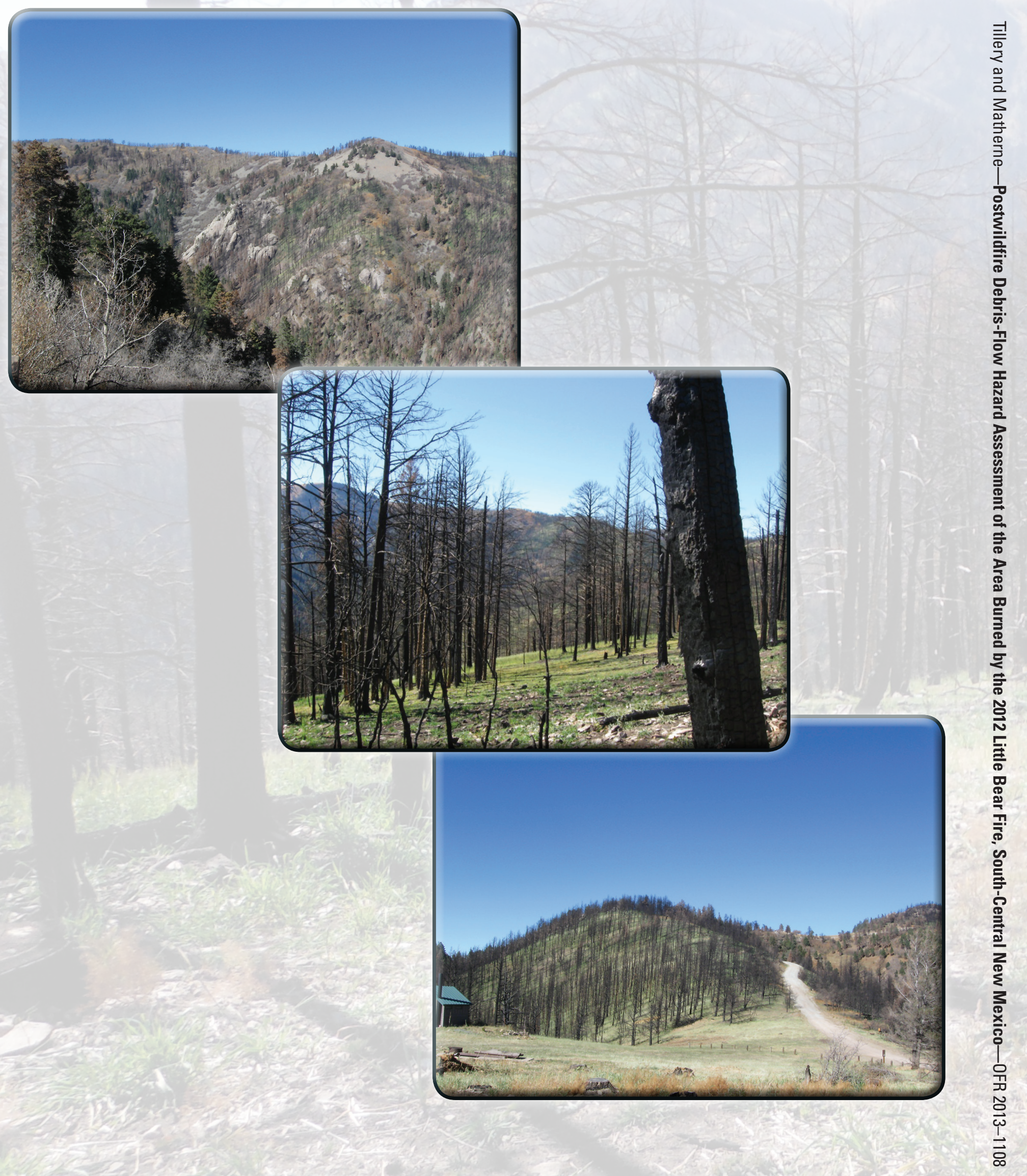

